\title{
Measurements of total alkalinity and inorganic dissolved carbon in the Atlantic Ocean and adjacent Southern Ocean between 2008 and 2010
}

\author{
U. Schuster ${ }^{1, *}$, A. J. Watson ${ }^{1, *}$, D. C. E. Bakker ${ }^{2}$, A. M. de Boer ${ }^{3,{ }^{*}}$, E. M. Jones ${ }^{4, *}$, G. A. Lee ${ }^{2}$, O. Legge ${ }^{2}$, \\ A. Louwerse ${ }^{1, *}$, J. Riley ${ }^{5}$, and S. Scally ${ }^{*}$ \\ ${ }^{1}$ College of Life and Environmental Sciences, University of Exeter, Exeter, EX4 4PS, UK \\ ${ }^{2}$ Centre for Ocean and Atmospheric Science, School of Environmental Sciences, University of East Anglia, \\ Norwich Research Park, Norwich, NR4 7TJ, UK \\ ${ }^{3}$ Department of Geological Sciences and Bolin Centre for Climate Research, Stockholm University, Stockholm, \\ Sweden \\ ${ }^{4}$ Alfred Wegener Institute for Polar and Marine Research, Climate Sciences, Postfach 120161, 27515 \\ Bremerhaven, Germany \\ ${ }^{5}$ International CLIVAR Project Office, National Oceanography Centre, Southampton, Waterfront Campus, \\ European Way, Southampton, SO14 3ZH, UK \\ * formerly at: School of Environmental Sciences, University of East Anglia, Norwich Research Park, Norwich, \\ NR4 7TJ, UK \\ Correspondence to: U. Schuster (u.schuster@exeter.ac.uk)
}

Received: 9 October 2013 - Published in Earth Syst. Sci. Data Discuss.: 8 November 2013

Revised: 13 March 2014 - Accepted: 16 March 2014 - Published: 6 May 2014

\begin{abstract}
Water column dissolved inorganic carbon and total alkalinity were measured during five hydrographic sections in the Atlantic Ocean and Drake Passage. The work was funded through the Strategic Funding Initiative of the UK's Oceans2025 programme, which ran from 2007 to 2012. The aims of this programme were to establish the regional budgets of natural and anthropogenic carbon in the North Atlantic, the South Atlantic, and the Atlantic sector of the Southern Ocean, as well as the rates of change of these budgets. This paper describes in detail the dissolved inorganic carbon and total alkalinity data collected along east-west sections at $47^{\circ} \mathrm{N}$ to $60^{\circ} \mathrm{N}, 24.5^{\circ} \mathrm{N}$, and $24^{\circ} \mathrm{S}$ in the Atlantic and across two Drake Passage sections. Other hydrographic and biogeochemical parameters were measured during these sections, and relevant standard operating procedures are mentioned here.

Over $95 \%$ of dissolved inorganic carbon and total alkalinity samples taken during the $24.5^{\circ} \mathrm{N}, 24^{\circ} \mathrm{S}$, and the Drake Passage sections were analysed onboard and subjected to a first-level quality control addressing technical and analytical issues. Samples taken along $47^{\circ} \mathrm{N}$ to $60^{\circ} \mathrm{N}$ were analysed and subjected to quality control back in the laboratory. Complete post-cruise second-level quality control was performed using crossover analysis with historical data in the vicinity of measurements, and data were submitted to the CLIVAR and Carbon Hydrographic Data Office (CCHDO), the Carbon Dioxide Information Analysis Center (CDIAC) and and will be included in the Global Ocean Data Analyses Project, version 2 (GLODAP 2), the upcoming update of Key et al. (2004).
\end{abstract}


Table 1. Data coverage and parameter measured.

\begin{tabular}{|c|c|c|c|}
\hline $\begin{array}{l}\text { Geographical region, } \\
\text { EXPO code }\end{array}$ & Repository reference & Coverage & Dates \\
\hline $\begin{array}{l}47 \text { to } 60^{\circ} \mathrm{N} \\
74 \mathrm{DI} 20080820\end{array}$ & doi:10.3334/CDIAC/OTG.CLIVAR_AR07W_74DI20080820 & $47.51^{\circ} \mathrm{N}$ to $60.6^{\circ} \mathrm{N} / 55.5^{\circ} \mathrm{W}$ to $11.1^{\circ} \mathrm{W}$ & $\begin{array}{l}20 \text { August to } \\
25 \text { September } 2008\end{array}$ \\
\hline $\begin{array}{l}24.5^{\circ} \mathrm{N} \\
74 \mathrm{DI} 20100106\end{array}$ & doi:10.3334/CDIAC/OTG.CLIVAR_A05_2010 & $23.3^{\circ} \mathrm{N}$ to $27.9^{\circ} \mathrm{N} / 79.9^{\circ} \mathrm{W}$ to $13.4^{\circ} \mathrm{W}$ & $\begin{array}{l}5 \text { January to } \\
19 \text { February } 2010\end{array}$ \\
\hline $\begin{array}{l}24^{\circ} \mathrm{S} \\
740 \mathrm{H} 20090307\end{array}$ & doi:10.3334/CDIAC/OTG.CLIVAR_A9.5_2009 & $37.4^{\circ} \mathrm{S}$ to $22.2^{\circ} \mathrm{S} / 53.5^{\circ} \mathrm{W}$ to $13.7^{\circ} \mathrm{E}$ & $\begin{array}{l}7 \text { March and } \\
21 \text { April } 2009\end{array}$ \\
\hline $\begin{array}{l}\text { Drake Passage, } \\
740 \mathrm{H} 20090203\end{array}$ & doi:10.3334/CDIAC/OTG.CLIVAR_A21_JC031_2009 & $\begin{array}{l}\text { A21: } 57.1^{\circ} \mathrm{S} \text { to } 64.1^{\circ} \mathrm{S} / 68.3^{\circ} \mathrm{W} \text { to } 63.1^{\circ} \mathrm{W} \text {, } \\
\text { SR01b: } 61.1^{\circ} \mathrm{S} \text { to } 54.7^{\circ} \mathrm{S} / 54.6 \text { to } 58.0^{\circ} \mathrm{W} \text {, } \\
\text { with an extension to } 53.14^{\circ} \mathrm{S} 58.00^{\circ} \mathrm{W}\end{array}$ & $\begin{array}{l}3 \text { February and } \\
3 \text { March } 2009\end{array}$ \\
\hline
\end{tabular}

\section{Introduction}

The world oceans had taken up approximately half of the anthropogenic carbon dioxide $\left(\mathrm{CO}_{2}\right)$ released by the burning of fossil fuel and producing cement between the Industrial Revolution and 1994 (Sabine et al., 2004). Without this sink of $\mathrm{CO}_{2}$, the atmospheric content of $\mathrm{CO}_{2}$ would be much higher than it is today, by approx. $80 \mathrm{ppm}$, depending on the variability of the source/sink balance since the industrial revolution. Moreover, the oceanic uptake of atmospheric $\mathrm{CO}_{2}$ is not uniform in either time or space, so that the future concentration of atmospheric $\mathrm{CO}_{2}$ is highly dependent on the behaviour and variability of this sink.

The control of the spatial and temporal variability of oceanic $\mathrm{CO}_{2}$ uptake is not well understood. One of the major influences is the Meridional Overturning Circulation (MOC) and in particular the Atlantic MOC, which have significant impact on climate and their influence on the carbon cycle (Peréz et al., 2013; Broecker and Peng, 1992; Watson et al., 1995).

In order to predict the future behaviour of the ocean sink, it is crucial to first get a better understanding of its present behaviour. To that end, sustained observations are needed of interior ocean biogeochemical and hydrographic parameters.

Between 2007 and 2012, a strategic research programme of the UK's National Environmental Research Council (NERC) Marine Centres, Oceans2025 (http://www. oceans2025.org/) was funded. Theme 1 - Ocean circulation, sea level and climate change - aimed to establish regional budgets of heat, freshwater, and carbon via the measurements of physical, chemical and biological parameters on a set of hydrographic sections in the Atlantic and the Atlantic sector of the Southern Ocean. To ensure high-quality measurements of carbon and transient tracers on these sections, a Strategic Funding Initiative (SOFI) was funded entitled "A carbon and transient tracer measurement programme in the Atlantic and Southern Ocean under Oceans2025". In this paper we describe the measurements of dissolved inorganic carbon (DIC) and total alkalinity (TA) performed on these sections.
These measurements were a UK-funded contribution to the international repeat hydrography effort (CLIVAR/GOSHIP programmes, http://www.go-ship.org/).

\section{Common sampling and analyses}

As part of SOFI, DIC and TA were analysed in seawater samples on five hydrographic sections in the Atlantic Ocean and the Atlantic sector of the Southern Ocean; Table 2 lists in north to south direction, geographical region (WOCE section), Expocode, cruise name, year, ship, and carbon PI along $47^{\circ} \mathrm{N}$ to $60^{\circ} \mathrm{N}$ in $2008,24.5^{\circ} \mathrm{N}$ in $2010,24^{\circ} \mathrm{S}$ in 2009 , and Drake Passages in 2009. The sections and positions of stations at which DIC and TA samples were taken are indicated in Fig. 1. Hereafter, the cruises are referred to by cruise name (i.e. DI332, DI346, JC032, and JC031).

All seawater samples for DIC and TA were drawn from the Niskin bottles of the conductivity/temperature/depth (CTD) rosette into either $500 \mathrm{~mL}$ or $250 \mathrm{~mL}$ borosilicate ground glass bottles according to the Standard Operating Procedure (SOP) \#1 (Dickson et al., 2007). In short, sample bottles are rinsed and then overfilled from the bottom. Subsequently during DI332, DI346, and JC032, samples were routinely poisoned by removing $1 \%$ of sample volume and adding $0.02 \%$ saturated mercuric chloride solution. Finally, the samples were stoppered and stored in a cool, dark place, until analysed either onboard or back in the laboratory. During JC031, samples were only poisoned upon collection if the analysis did not take place within $8 \mathrm{~h}$ for surface samples and within $20 \mathrm{~h}$ for deep samples. Approximately $30 \%$ of JC031 samples were poisoned.

DIC was analysed by coulometry (Johnson et al., 1985, 1987, 1993) following SOP \#2 (Dickson et al., 2007) and TA by open cell potentiometric titration (Mintrop et al., 2000) following SOP \#3b (Dickson et al., 2007). Two types of instruments were used: (i) for DIC only, a stand-alone extraction unit (Robinson and Williams, 1991) connected to a coulometer (UIC, USA, model 5011), and (ii) for both DIC and TA, two Versatile INstrument for the Determination of Titration Alkalinity (VINDTA version 3C, Marianda, 
Table 2. Geographic region (WOCE section), Expocode, cruise name, year, ship, and carbon PI for each cruise.

\begin{tabular}{llllll}
\hline $\begin{array}{l}\text { Geographical region } \\
\text { (WOCE section) }\end{array}$ & Expocode & $\begin{array}{l}\text { Cruise } \\
\text { name }\end{array}$ & Year & Ship & Carbon PI \\
\hline $\begin{array}{l}47^{\circ} \mathrm{N} \text { to } 60^{\circ} \mathrm{N} \\
(\text { AR7W and AR7E) }\end{array}$ & $74 \mathrm{DI} 20080820$ & DI332 & 2008 & $\begin{array}{l}\text { RRS } \\
\text { Discovery }\end{array}$ & Ute Schuster \\
$\begin{array}{l}24.5^{\circ} \mathrm{N} \\
(\mathrm{A} 05)\end{array}$ & $74 \mathrm{DI} 20100106$ & DI346 & 2010 & $\begin{array}{l}\text { RRS } \\
\text { Discovery }\end{array}$ & Ute Schuster \\
$\begin{array}{l}24^{\circ} \mathrm{S} \\
(\mathrm{A} 09.5)\end{array}$ & $740 \mathrm{H} 20090307$ & JC032 & 2009 & $\begin{array}{l}\text { RRS } \\
\text { James Cook }\end{array}$ & Ute Schuster \\
$\begin{array}{l}\text { Drake Passage } \\
(\text { A21 and SR01b) }\end{array}$ & $740 \mathrm{H} 20090203$ & JC031 & 2009 & $\begin{array}{l}\text { RRS } \\
\text { James Cook }\end{array}$ & Dorothee Bakker \\
\hline
\end{tabular}

* The denotation A21/SR01 has been used both for cruises in the western Drake Passage (e.g. the western section on JC031 and 06MT11_5, Chipman et al., 1994) or in the central Drake Passage (e.g. LMG200603 and LMG200909).

(a)

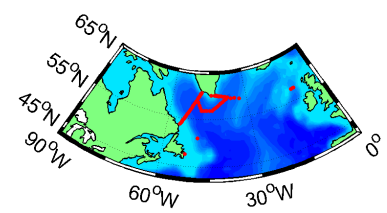

(b)

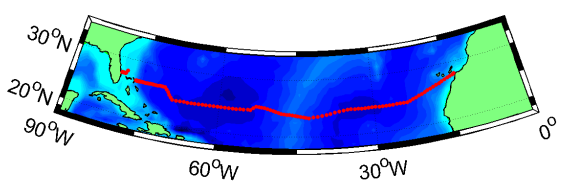

(c)

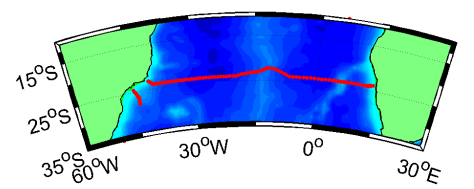

(d)

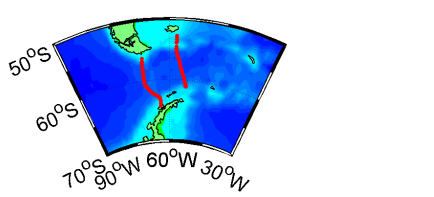

Figure 1. Positions of stations at which DIC and TA samples were taken in the Atlantic and Drake Passage during (a) DI332, (b) DI346, (c) JC032, and (d) JC031 (A21 in the west and SR1b in the east).

Germany, SN \#004 and \#007), connected to a coulometer (UIC, USA, model 5011) and a Titrino (Metrohm UK Ltd.).

For the analysis, seawater is allowed into the stand-alone extractor by gravity, whilst it is drawn into the VINDTAs by slow peristaltic pump. Glass pipettes, approx. $20 \mathrm{~mL}$ for DIC and approx. $100 \mathrm{~mL}$ for TA, are first rinsed with new seawater sample before being filled to overflowing. The volumes of these pipettes were accurately calibrated before and after the cruises and the laboratory analysis.

The VINDTAs' sample pipettes and alkalinity titration cell are thermostated at $25^{\circ} \mathrm{C}$, and seawater samples were brought up to $25^{\circ} \mathrm{C}$ prior to analysis. Conversely, the standalone extractor's DIC sample pipette is insulated but not water jacketed, and seawater samples were not warmed up prior to analyses.

During DIC analysis, all inorganic dissolved carbon is converted to $\mathrm{CO}_{2}$ by addition of excess phosphoric acid ( $1 \mathrm{M}$, $8.5 \%$ ) to a calibrated volume of seawater sample. Oxygenfree-nitrogen gas (OfN, BOC, UK), after passing through soda lime to remove any traces of $\mathrm{CO}_{2}$, is used to carry the evolving $\mathrm{CO}_{2}$ to the coulometer cell, where all $\mathrm{CO}_{2}$ is quantitatively absorbed, forming an acid that is coulometrically titrated.

During TA analysis, aliquots of $0.1 \mathrm{M}$ hydrochloric acid are added to the seawater sample, and the electromotive force is measured by a $\mathrm{pH}$ and reference electrode assembly. TA is calculated using a Gran plot and curve fit (Mintrop et al., 2000).

A $500 \mathrm{~mL}$ bottle allows both DIC and TA to be analysed twice per sample (as a successive in-bottle duplicate), thereby providing information on the precision of measurements. A $250 \mathrm{~mL}$ bottle only allows DIC and TA to be analysed once, but as done during DI332, duplicate samples from the same Niskin allow for same-depth duplicates.

The VINDTAs, and the stand-alone extractor during JC031 and JC032, were installed in a seagoing laboratory container of the Laboratory for Global Marine and Atmospheric Chemistry (LGMAC) of UEA, UK, on the ships' aft decks. During DI346, JC031, and JC032, DIC and TA analyses and first-level quality control were performed at sea, and data were submitted, together with other cruise parameters, at end of the cruise to the CLIVAR and Carbon Hydrographic Data Office (CCHDO). Samples were collected and stored during DI332 for VINDTA analysis back in the laboratory. Data submitted after second-level quality control are available at Carbon Dioxide Information Analysis Center 
Table 3. Total number of (i) stations sampled, (ii) depths sampled, (iii) DIC and TA samples left after first- and second-level quality control for each cruise.

\begin{tabular}{|c|c|c|c|c|}
\hline \multirow[t]{3}{*}{ Cruise name } & \multicolumn{4}{|c|}{ Total number of } \\
\hline & \multirow[t]{2}{*}{$\begin{array}{l}\text { stations } \\
\text { sampled }\end{array}$} & \multirow[t]{2}{*}{$\begin{array}{l}\text { depths } \\
\text { sampled }\end{array}$} & \multicolumn{2}{|c|}{$\begin{array}{l}\text { depths reported } \\
\text { to data centres }\end{array}$} \\
\hline & & & $\begin{array}{r}\text { of which TA } \\
\text { values }\end{array}$ & $\begin{array}{r}\text { of which DIC } \\
\text { values }\end{array}$ \\
\hline DI332 & 74 & 297 & 239 & 288 \\
\hline DI346 & 135 & 1427 & 1226 & 1322 \\
\hline $\mathrm{JC} 032$ & 116 & 1606 & 1504 & 1475 \\
\hline JC031 & 63 & 1380 & 1044 & 1060 \\
\hline
\end{tabular}

(CDIAC) and are included in the GLODAP 2 (Global Ocean Data Analyses Project, version 2) effort.

Details of the measurements of temperature, salinity, and nutrients are not included in this paper as its emphasis is on DIC and TA, but sampling, analysis, and quality control procedures have followed recommended standard operating procedures developed during the era of the World Ocean Circulation Experiment (WOCE) in the 1990s, which are now maintained by GO-SHIP (Hood et al., 2010). WOCE and GO-SHIP SOPs are found for salinity in Stalcup (1991) and Kawano (2010), for nutrients in Gordon et al. (1993) and Hydes et al. (2010), and for dissolved oxygen in Culberson (1991) and Langdon (2010). Details of the cruises covered in this paper are given in Bacon (2010) for DI332, King and Hamersley (2012) for DI346, King and Hamersley (2010) for JC032, and McDonagh and Hamersley (2009) for JC031.

\section{Specific cruises' sampling and analyses}

Table 3 lists the total number of stations sampled, depths sampled, and DIC and TA values reported for each cruise.

\subsection{DI332, "Arctic gateway"}

RRS Discovery cruise DI332, between 20 August and 25 September 2008 from Canada, via Greenland, to Scotland, was planned as one cruise in the vicinity of WOCE section AR7, as an occupation of both the western Labrador Sea part (AR7W) and the eastern part across the Irminger Basin, Iceland Basin, Rockall-Hatton Plateau and Rockall Trough (AR7E) (cruise track in Fig. 1a; Bacon, 2010). AR7W was completed, whilst AR7E could not completed due to mechanical failures and foul weather.

A total of 74 CTD stations were occupied with a $24 \times 20$ litre Niskin bottle rosette. West of Greenland (AR7W), Niskins of 28 stations were sampled into $250 \mathrm{~mL}$ bottles for DIC and TA analyses. Depths throughout the water column were sampled, with a minimum of three duplicate depths at each of the sampled stations (one set of duplicates at the deepest depth, one at the shallowest depth, and one set at an intermediate depth), which served as same-depth duplicates.

A total of 297 depths were sampled and stored for later analysis back in the laboratory, which was carried out between 30 July and 8 October 2009 using VINDTA SN \#007. Instrument calibration was done throughout the analysis using certified reference materials (CRMs, batch 90). Following first- and second-level quality control (see Sect. 4), 290 sample values of 21 stations were left, which contained 239 TA and 288 DIC values.

Final second-level quality-controlled data have been submitted to British Oceanographic Data Centre (BODC), and are included in the GLODAP 2 effort, via CDIAC.

\subsection{DI346, $24.5^{\circ} \mathrm{N}$ in 2010}

RRS Discovery cruise DI346 was between 5 January and 19 February 2010 from The Bahamas to Lisbon, Portugal, along nominal latitude $24.5^{\circ} \mathrm{N}$ in the Atlantic (cruise track in Fig. 1b; King and Hamersley, 2012). It was a repeat occupation of the section, previously occupied including carbon measurements in 2004 (e.g. Brown et al., 2010), 1998 (e.g. Macdonald et al., 2003), and 1992 (e.g. Rosón et al., 2003).

A total of 135 CTD stations were occupied with a $24 \times 20$ litre Niskin bottle rosette. Samples for DIC and TA were not taken from all depths at each station. Generally, 16 depths were sampled from each station, including the shallowest and deepest ones with the other depths selected to allow for optimum interpolation across the whole section. Initially, all samples were taken in $500 \mathrm{~mL}$ bottles. From Station 34 until Station 129 , every third station was fully sampled in $250 \mathrm{~mL}$ bottles and initially stored, with four depths of each of these stations sampled in duplicate bottles. All other stations, sampled in $500 \mathrm{~mL}$ bottles, were analysed as a priority, and once profiles for these stations had been obtained, selected $250 \mathrm{~mL}$ bottles were analysed in order to strengthen areas of missing or suspect data.

Instrument calibration was done throughout the cruise using CRMs (batch 97), and first-level quality-controlled DIC and TA data were submitted, together with other cruise 
Table 4. Precision of DIC and TA measurements, defined as the standard deviation of in-bottle duplicate measurements during DI346, JC032, and JC031, and of same-depth duplicate measurements during DI332.

\begin{tabular}{lccc|cc}
\hline & \multicolumn{3}{c|}{$\begin{array}{c}\text { DIC precision } \\
{\left[\mu \mathrm{mol} \mathrm{kg}{ }^{-1}\right]}\end{array}$} & \multicolumn{2}{c}{$\begin{array}{c}\text { TA precision } \\
{\left[\mu \mathrm{mol} \mathrm{kg} \mathrm{kg}^{-1}\right]}\end{array}$} \\
\cline { 2 - 6 } & VINDTA & VINDTA & $\begin{array}{c}\text { Stand-alone } \\
\text { extractor }\end{array}$ & VINDTA & VINDTA \\
& SN \#004 & SN \#007 & N04 & SN \#007 \\
\hline DI332 & NA & \pm 1.4 & NA & NA & \pm 0.9 \\
DI346 & \pm 1.4 & \pm 1.8 & NA & \pm 1.2 & \pm 1.1 \\
JC032 & NA & \pm 1.4 & \pm 1.7 & \pm 1.7 & \pm 1.8 \\
JC031 & NA & \pm 2.7 & \pm 1.4 & \pm 2.3 & \pm 2.7 \\
\hline
\end{tabular}

Table 5. Accuracy of DIC and TA measurements for each instrument and section. The accuracy is defined as the standard deviation of CRM values around the mean, after first-level QC and second-level QC using the CARINA dataset. A second-level QC with new data in GLODAP 2 recommends to lower TA during JC031 by $10 \mu \mathrm{mol} \mathrm{kg}^{-1}$ (R. Key, personal communication, 2014).

\begin{tabular}{lccc|cc}
\hline & \multicolumn{3}{c|}{$\begin{array}{c}\text { DIC accuracy } \\
{\left[\mu \mathrm{mol} \mathrm{kg}{ }^{-1}\right]}\end{array}$} & \multicolumn{2}{c}{$\begin{array}{c}\text { TA accuracy } \\
{\left[\mu \mathrm{mol} \mathrm{kg}^{-1}\right]}\end{array}$} \\
\cline { 2 - 6 } & VINDTA & VINDTA & $\begin{array}{c}\text { Stand-alone } \\
\text { extractor }\end{array}$ & VINDTA & VINDTA \\
& SN \#004 & SN \#007 & N04 & SN \#007 \\
\hline DI332 & NA & \pm 2.1 & NA & NA & \pm 2.1 \\
DI346 & \pm 3.0 & \pm 3.0 & NA & \pm 2.1 & \pm 3.0 \\
JC032 & NA & \pm 3.1 & \pm 3.2 & \pm 3.2 & \pm 3.4 \\
JC031 & NA & \pm 3.0 & \pm 3.0 & \pm 3.0 & \pm 3.0 \\
\hline
\end{tabular}

parameters, at end of cruise to the CLIVAR and Carbon Hydrographic Data Office (CCHDO), and final second-level quality-controlled data (1226 TA and 1322 DIC) have been resubmitted to CCHDO and will be included in the GLODAP 2 effort, via CDIAC.

\subsection{JC032, $24^{\circ} \mathrm{S}$ in 2009}

RRS James Cook cruise JC032 was between 7 March and 21 April 2009 from Montevideo, Uruguay, to Walvis Bay, Namibia, across the Brazil Current and along nominal latitude $24^{\circ} \mathrm{S}$ in the Atlantic Ocean (cruise track in Fig. 1c; King and Hamersley, 2010).

A total of 118 CTD stations were occupied with 24 rosettes of which 4 were $20 \mathrm{~L}$ Niskin bottles for near-surface sampling and the remaining depths sampled using $10 \mathrm{~L}$ Niskin bottles. For DIC and TA, 116 stations were sampled. At each station sampled, the top two and bottom two were always sampled for DIC and TA, with in-between depths sampled alternatively for optimum interpolation across the whole section.

All samples were taken in $500 \mathrm{~mL}$ bottles with duplicate analyses DIC and TA done of each bottle, first DIC by the stand-alone extractor and VINDTA SN \#007, followed by TA by the VINDTA SN \#004 and \#007 (the DIC on VINDTA SN \#004 was inoperable during JC032).

Instrument calibration was done throughout the cruise using CRMs (bath 90), and first-level quality-controlled DIC and TA data were submitted, together with other cruise parameters, at end of cruise to the CLIVAR and Carbon Hydrographic Data Office (CCHDO), and final second-level quality-controlled data (1504 TA and 1475 DIC) have been re-submitted to CCHDO and will be included in the GLODAP 2 effort, via CDIAC.

\subsection{JC031, Drake Passage in 2009}

RRS James Cook cruise JC031 took place between 3 February and 3 March 2009 from Punta Arenas, Chile, to Montevideo, Uruguay, across Drake Passage (WOCE sections A21 and SR01b, cruise track in Fig. 1d; McDonagh and Hamersley, 2009). Section A21 (also known as SR01) had been occupied before in 1990 and 1999 with DIC measurements made in 1990 (Chipman et al., 1994), and Sect. SR01b, located further to the east, has been occupied every year, except two, since 1993, with the 2009 occupation being the first time DIC and TA measurements were made here.

A total of 84 CTD stations were occupied with a 24-bottle Niskin bottle rosette with $10 \mathrm{~L}$ and $20 \mathrm{~L}$ bottles. For DIC and TA, a total of 63 stations were sampled. Samples for DIC and TA were taken from depths throughout the water column at each station, with more samples taken in the top $1000 \mathrm{~m}$ to aid resolving vertical structure.

All samples were taken in $500 \mathrm{~mL}$ bottles with duplicate analyses for DIC and TA done of each bottle, first DIC by the stand-alone extractor and VINDTA SN \#007, followed 
by TA by the VINDTA SN \#004 and \#007 (the DIC part of VINDTA SN \#004 was inoperable during JC031).

Instrument calibration was done throughout the cruise using CRMs (batch 90 and 92); data quality assurance and initial first-level data quality control was done throughout the cruise, with full first-level and second-level quality control done post cruise. The final data (1044 TA and 1060 DIC) will be included in the GLODAP 2 effort, via CDIAC.

\section{Quality control}

Quality control (QC) of DIC and TA measurements was done in two distinct steps: during first-level QC, data are checked for obvious outliers, and technical or analytical problems during measurements; during second-level QC, cross-over analysis is performed with other sections and corrections identified where necessary. Essentially, first-level QC addresses precision whilst second-level QC addresses accuracy.

\subsection{First-level QC}

Throughout DIC and TA analyses, regular $500 \mathrm{~mL}$ certified reference materials (CRMs) were analysed as in-bottle duplicates. Generally during one day's analyses, one CRM was run after the coulometer cell had stabilised, one mid-cell, and one at the end. This resulted in generally three, occasionally two CRMs being run per CTD cast. CRM batches used were \#90 during DI332, \#97 during DI346, \#90 during JC032, and \#90 and \#92 during JC031.

Initial DIC and TA calibrations were done onboard (DI346, JC032, and JC031) or in the laboratory (DI332) by correcting all DIC and TA values by the difference between the mean of all CRM measurements and the CRM values of the respective batches used.

WOCE quality flags (Joyce and Corry, 1994) were then assigned to each sample, initially flag 2 for all measurements. All DIC and TA were then checked for obvious outliers, identified by unusually high differences between duplicates, unusually high differences to neighbouring Niskins after optimum interpolation, unusually long TA or DIC titration times, non-smooth titration curves, unusually high residuals in calculated TA. All such outliers were then flagged as 4 when identified as a bad measurement, and flagged as 3 when uncertain. Figure 2 shows the CRM values for DIC and TA during the analyses of samples from the four cruises. Included are samples with WOCE flag 2 or 3 only, but prior to final recalibration; hence the plots indicate the variability of the instruments' response over time. Calibrations were checked and subsequently re-done for different TA acid batches, for different CRMs (e.g. JC031), and different sample pipette volumes (e.g. DI346). Finally, when duplicates' flags were 2 or 3, the mean DIC or TA of the two was reported with the highest WOCE flag of the duplicates for DI346, JC032, and JC031. The precision of DIC and TA measurements is given in Table 4, defined for DI346, JC032, and JC031 as the standard deviation of in-bottle duplicate measurements, and for DI332 as same-depth duplicate measurements (Dickson et al., 2007; SOP \#23).

\subsection{Second-level QC}

Second-level QC was carried out using the Matlab crossover analysis toolbox (Tanhua, 2010). This method evaluates the consistency of deep-water measurements by comparing them with data from a reference data set. The reference data used were the CARINA Atlantic data set (updated August 2012) at http://cdiac.ornl.gov/ftp/oceans/2nd_QC_Tool/refdata/. Station profiles from the cruises in question were compared to profiles from cruises in the reference data set which were within a certain horizontal distance (in this case $2^{\circ}$ latitude). The result of each comparison between two cruises is an offset, which for TA and DIC is additive. For DI346 and JC032, data from below $1500 \mathrm{~m}$ depth were compared and the profiles were based on density, whereas for DI332 the minimum depth was $1900 \mathrm{~m}$ and the profiles were based on depth (following Tanhua, 2010; Olsen et al., 2009). DI332 was compared with 14 cruises, DI346 with 9 cruises, JC032 with 2 cruises and JC031 with 2 cruises. This comparison with the CARINA data set, showed no offsets larger than $4 \mu \mathrm{mol} \mathrm{kg}{ }^{-1}$ for DIC and $6 \mu \mathrm{mol} \mathrm{kg}{ }^{-1}$ for TA (Wanninkhof et al., 2003). Therefore, the data that we submitted to BODC, CCHDO, and CDIAC contained no corrections, and contain the accuracies given in Table 5, defined for TA measurements as the standard deviation of CRMs per acid batch, and for DIC measurements as the standard deviation of all CRMs per cruise (Dickson et al., 2007; SOP \#23).

The GLODAP initiative (Key et al., 2004), now in its version 2, compares newly added measurements since the CARINA initiative in the Atlantic, and contains the most comprehensive global data set available. This GLODAP 2 initiative has currently (April 2014) identified no recommendations for DIC and TA during DI332, DI346, and JC032, whilst it recommends to lower TA for JC031 by $10 \mu \mathrm{mol} \mathrm{kg}-1$ (R. Key, personal communication, 2014). 

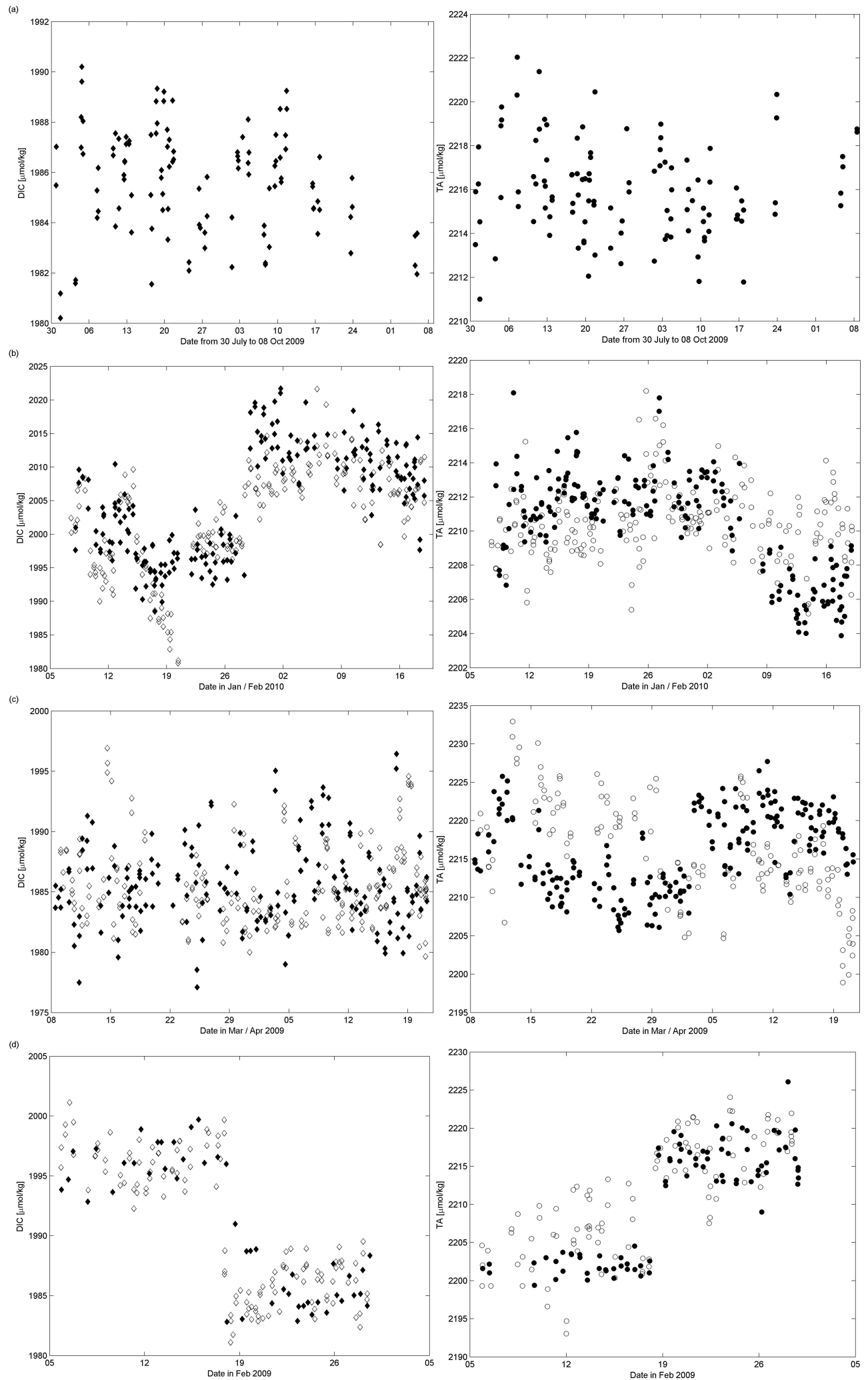

Figure 2. DIC and TA values of CRM analyses over time for (a) DI332, (b) DI346, (c) JC032, and (d) JC031. Solid symbols are DIC and TA values analysed on VINDTA \#007, whilst open symbols are from VINDTA \#004 during DI346 and from the stand-alone extractor during JC031 and JC032; only one instrument was used for samples from DI332. Please note that these values are plotted after outliers were identified and removed (see text in Sect. 4.1), but prior to re-calibration; offsets in these plots indicate for example a change in CRM (e.g. JC031) or a change in sample pipette volume (DI346), and different acid batches for TA. 
Acknowledgements. We are very grateful to captains, officers, and crew of RRS Discovery and RRS James Cook for their support during the fieldwork and principal scientific officers S. Bacon (DI332), E. McDonagh (JC031), and B. King (JC032 and DI346) for support of the carbon research. We acknowledge funding by UK's NERC Strategic Ocean Funding Initiative (SOFI) NE/F01242X/1, supporting the UK Oceans 2025 programme (2007 to 2012), the EU CARBOCHANGE project (264879) and the UK Ocean Acidification Programme (NE/H017046/1) for supporting staff time for this work. We thank E. Madsen, E. Rathbone, I. Salter, J. Allen, R. Pidcock, J. Frommolet, K. Cox and S. Seeyave for taking samples for DIC and TA during D332. We also thank the editor, one anonymous reviewer and Are Olsen for careful comments, which have improved the manuscript.

U. Schuster was PI of carbon sampling and analyses for DI332, JC032, and DI346. A. J. Watson was PI of the SOFI grant. D. C. E. Bakker was PI of carbon sampling and analyses for JC031. A. M.de Boer was watch keeper during JC032. E. M. Jones was watch keeper during JC031. G. A. Lee was watch keeper during DI346. O. Legge was watch keeper during DI346 and aided quality control of data. A. Louwerse was watch keeper during DI346. J. Riley was watch keeper during JC031. S. Scally was watch keeper during JC032.

Edited by: D. Carlson

\section{References}

Bacon, S.: RRS Discovery cruise 332, 21 August to 25 September 2008. Arctic Gateway (WOCE AR7), National Oceanography Centre Southampton, Southampton, UK, National Oceanography Centre Southampton Cruise Report 53, 129 pp., 2010.

Broecker, W. S. and Peng, T. H.: Interhemispheric Transport of Carbon-Dioxide by Ocean Circulation, Nature, 356, 587-589, 1992.

Brown, P. J., Bakker, D. C. E., Schuster, U., and Watson, A. J.: Anthropogenic carbon accumulation in the subtropical North Atlantic, J. Geophys. Res., 115, C04016, doi:10.1029/2008JC005043, 2010.

Chipman, D. W., Takahashi, T., Breger, D., and Sutherland, S.: Carbon dioxide, hydrographic, and chemical data obtained during the $R / V$ Meteor cruise $11 / 5$ in the South Atlantic and northern Weddell Sea areas (WOCE sections A-12 and A-21), Oak Ridge National Laboratory (ORNL)/ Carbon Dioxide Information Analysis Center (CDIAC), Oak Ridge, Tennessee, USA, NDP 045, 61 pp., 1994.

Culberson, C. H.: Dissolved oxygen, in: WOCE operating manual, WHP Office Report WHPO 91-1, WOCE Report No. 68/91, available at: http://whpo.ucsd/edu/manuals/pdf/91-1/ stal.pdf (last access: 10 March 2014), 15 pp., 1991.

Dickson, A. G. and Sabine, C. L.: Guide to best practice for ocean $\mathrm{CO}_{2}$ measurments, PICES Special Publication, 3, 191 pp., 2007.

Gordon, L. I., Jennings, J. C. J., Ross, A. A., and Krest, J. M.: A suggested protocol for continuous flow automated analysis of seawater nutrients (phosphate, nitrate, nitrite and silicite acid) in the WOCE Hydrographic Program and the Joint Global Ocean Fluxes Study, in: WOCE operating manual, WHP Office Report WHPO 91-1, WOCE Report No. 68/91, available at: http:// whpo.ucsd/edu/manuals/pdf/91-1/stal.pdf (last access: 10 March 2014), 55 pp., 1993.

Hood, E. M., Sabine, C. L., and Sloyan, B. M.: The GO-SHIP Repeat Hydrography Manual: a Collection of Expert Reports and Guidelines, IOCCP Report Number 14, OCPO Publication Series Number 134; available at: http://www.go-ship.org/ HydroMan.html. (last access: 10 March 2014), 2010.

Hydes, D. J., Aoyama, M., Aminot, A., Bakker, K., Becker, S., Coverly, S., Daniel, A., Dickson, A. G., Grosso, O., Kerouel, R., van Ooijen, J., Sato, K., Tanhua, T., Woodward, E. M. S., and Zhang, J. Z.: Determination of dissolved nutrients (N, P, Si) in seawater with high precision and inter-comparability using gas-segmented continuous flow analysers, in: The GO-SHIP Repeat Hydrography Manual: a Collection of Expert Reports and Guidelines, edited by: Hood, E. M., Sabine, C. L., and Sloyan, B. M., 87 pp., 2010.

Johnson, K. M., King, A. E., and Sieburth, J. M.: Coulometric $\mathrm{TCO}_{2}$ analyses for marine studies; an introduction, Mar. Chem., 16, 6182, 1985.

Johnson, K. M., Sieburth, J. M., Williams, P. J. 1., and Braendstroem, L.: Coulometric total carbon dioxide analysis for marine studies: automation and calibration, Mar. Chem., 21, 117-133, 1987.

Johnson, K. M., Wills, K. D., Butler, D. B., Johnson, W. K., and Wong, C. S.: Coulometric Total Carbon-Dioxide Analysis for Marine Studies - Maximizing the Performance of an Automated Gas Extraction System and Coulometric Detector, Mar. Chem., 44, 167-187, 1993.

Joyce, T. and Corry, C.: Requirements for WOCE hydrographic program data reporting, WOCE Hydrographic Program Office, La Jolla, California, USA, WHPO Publication 90-1, review 2, 145 pp., 1994.

Kawano, T.: Method for Salinity (Conductivity Ratio) Measureme, in: The GO-SHIP Repeat Hydrography Manual: a Collection of Expert Reports and Guidelines, edited by: Hood, E. M., Sabine, C. L., and Sloyan, B. M., 2010.

Key, R. M., Kozyr, A., Sabine, C. L., Lee, K., Wanninkhof, R., Bullister, J. L., Feely, R. A., Millero, F. J., Mordy, C., and Peng, T. H.: A global ocean carbon climatology: Results from Global Data Analysis Project (GLODAP), Global Biogeochem. Cy., 18, GB4031, doi:10.1029/2004GB002247, 2004.

King, B. A. and Hamersley, D. R. C.: RRS James Cook cruise JC032, 07 March to 21 April 2009. Hydrographic sections accross the Brazil Current and at $24^{\circ} \mathrm{S}$ in the Atlantic, National Oceanogrpahic Centre Southampton, Southampton, UK, 173 pp., 2010.

King, B. A. and Hamersley, D. R. C.: RRS Discovery Cruise 346; 05 January to 19 February 2010; the 2010 transatlantic hydrography section at $24.5^{\circ} \mathrm{N}$, National Oceanography Centre, Southampton, Southampton, UK, 2012.

Langdon, C.: Determination of dissolved oxygen in seawater by Winkler titration using the amperometric technique, in: The GOSHIP Repeat Hydrography Manual: a Collection of Expert Reports and Guidelines, edited by: Hood, E. M., Sabine, C. L., and Sloyan, B. M., 18 pp., 2010.

Macdonald, A. M., M.O., B., Wanninkhof, R., Lee, K., and Wallace, D. W. R.: A 1998-1992 comparison of inorganic carbon and its transport across $24.5^{\circ} \mathrm{N}$ in the Atlantic, Deep-Sea Res. Pt. II, 50, 3041-3064, 2003. 
McDonagh, E. L. and Hamersley, D. R. C.: RRS James Cook Cruise JC031, 03 Feb to 03 Mar 2009. Hydrographic sections of Drake Passage, National Oceanography Centre, Southampton, Southampton, UKNOCS cruise report 39, 170 pp., 2009.

Mintrop, L., Perez, F. F., González-Dávila, M., Santana-Casiano, M. J., and Körtzinger, A.: Alkalinity determination by potentiometry: Intercalibration using three different methods, Ceinc. Mar., 26, 23-37, 2000.

Olsen, A., Key, R. M., Jeansson, E., Falck, E., Olafsson, J., van Heuven, S., Skjelvan, I., Omar, A. M., Olsson, K. A., Anderson, L. G., Jutterström, S., Rey, F., Johannessen, T., Bellerby, R. G. J., Blindheim, J., Bullister, J. L., Pfeil, B., Lin, X., Kozyr, A., Schirnick, C., Tanhua, T., and Wallace, D. W. R.: Overview of the Nordic Seas CARINA data and salinity measurements, Earth Syst. Sci. Data, 1, 25-34, doi:10.5194/essd-1-25-2009, 2009.

Peréz, F. F., Mercier, H., Vázquez-Rodriguez, M., Lherminier, P., Velo, A., Pardo, P. C., Rosón, G., and Ríos, A. F.: Atlantic Ocean $\mathrm{CO}_{2}$ uptake reduced by weakening of the meridional overturning circulation, Nat. Geosci., 6, 146-152, doi:10.1038/NGEO1680, 2013.

Robinson, C. and Williams, P. J. L.: Development and assessment of an analytical system for the accurate and continual measurement of total dissolved inorganic carbon, Mar. Chem., 34, 157-175, 1991.
Rosón, G., Ríos, A. F., Pérez, F. F., Lavin, A., and Bryden, H. L.: Carbon distribution, fluxes, and budgets in the subtropical North Atlantic Ocean (24.5 N). J. Geophys. Res., 108, 3144, doi:10.1029/1999JC000047, 2003.

Sabine, C. L., Feely, R. A., Gruber, N., Key, R. M., Lee, K., Bullister, J. L., Wanninkhof, R., Wong, C. S., Wallace, D. W. R., Tilbrook, B., Millero, F. J., Peng, T. H., Kozyr, A., Ono, T., and Rios, A. F.: The oceanic sink for anthropogenic $\mathrm{CO}_{2}$, Science, 305, 367-371, 2004.

Stalcup, M. C.: Salinity measurements, in: WOCE operating manual, WHP Office Report WHPO 91-1, WOCE Report No. 68/91, available at: http://whpo.ucsd/edu/manuals/pdf/91-1/stal. pdf (last access: 10 March 2014), 9 pp., 1991.

Tanhua, T.: Matlab Toolbox to Perform Secondary Quality Control (2nd QC) on Hydrographic Data, CDIAC, Oak Ridge, Tennessee, 2010.

Wanninkhof, R., Peng, T.-H., Huss, B., Sabine, C. L., and Lee, K.: Comparison of inorganic carbon system parameters measured in the Atlantic Ocean from 1990 to 1998 and recommended adjustments, Oak Ridge National Laboratory, Oak Ridge, Tennessee CDIC-140, 59 pp., 2003.

Watson, A. J., Nightingale, P. D., and Cooper, D. J.: Modelling atmosphere-ocean $\mathrm{CO}_{2}$ transfer, Philos. T. R. Soc. Lon. B, 348, 125-132, 1995. 